\title{
Missed Opportunities for Comprehensive Security Sector Reform in Mali
}

\author{
Zeïni Moulaye \\ Foreign Affairs Advisor and former Minister of Transports \\ and Tourism for Mali
}

\section{Introduction}

Following the democratic revolution in March 1991, Mali became an example and even a model of democratic governance in West Africa, including in the area of transformational management of the security sector. The events of 2012 however called all this into question. That year was marked by the resurgence in the Tuareg rebellion in January, followed by a coup d'état in March against a regime that the organisers of the putsch described as "incompetent" (Konaté 2013: 252). Then, in April, Islamist jihadist movements also made their appearance. A temporary alliance of the rebellion, the jihadists and other transnational criminal operators (Moulaye 2014) including drug traffickers was created, which enabled them to occupy the northern regions of the country, constituting two thirds of the national territory. For almost a year, these criminals pillaged, plundered, raped, destroyed and carried out grave human rights violations marked by an unprecedented degree of violence. These events revealed the overall lack of governance in Mali, in the political, economic, social and cultural and security spheres.

The serious shortcomings in the security sector had not been addressed by the timid process of security sector reform initiated by the government of General Amadou Toumani Touré in 2005. Why? Most certainly due to a

How to cite this book chapter:

Moulaye, Z. 2015. Missed Opportunities for Comprehensive Security Sector Reform in Mali. In: Bryden, A and Chappuis, F (eds.) Learning from West African Experiences in Security Sector Governance, Pp. 79-95. London: Ubiquity Press. DOI: http:// dx.doi.org/10.5334/bau.e. License: CC-BY 4.0. 
lack of leadership, political backing and acceptance. It appears that these grave shortcomings were the result of a rear-guard conservatism on the part of certain senior officers who wanted to cling to their often undeserved privileges in terms of recruitment, rank, positions and allowances. They risked losing such privileges if the reform process led to sound security sector governance, democratic control, transparent management, efficiency and accountability. The situation can be attributed first and foremost to the lack of political will at the highest level since the head of state, according to the constitution, is commander in chief of the armed forces and in this case, was also a former senior officer.

The modern history of Mali has provided various remarkable opportunities to redesign and reform the security sector. The first of these was at the time of independence on 22 September 1960. At the time, the new Malian authorities called on all citizens serving in the ranks of the French armed forces and within the colonial security services to come back to their newly independent homeland to set up the Malian armed forces and Malian security services. The concept and practice of security was not however redesigned to take into account the new political, economic and social and cultural realities of the nascent state of Mali. The defence and security forces (DSF) were established immediately after independence, but their members were not 'reprogrammed'. During the colonial period, these personnel had been 'trained' to serve the French administration against the same colonised peoples who had now declared their independence. As a result, unwittingly, the mind set (domination) and behaviour (repressive) of the troops at the disposal of the new regime were the same as within the colonial forces. In their defence, it is most likely that this was exactly what the new leaders wanted, as they sought to entrench their authority and power. This would later lead to the establishment of a dictatorial regime.

The start of a democratic era on 26 March 1991 provided a second opportunity to redesign and reform the security sector. Already in 1990, the rebellion in the north of Mali had revealed the scope of proliferation of small arms and light weapons, as well as their devastating effects on human security. At the time of the democratic revolution in 1991, the security forces were reviled and accused of being 'repressive forces', at the service of a 'dictator'. The forces were such a subject of public opprobrium that during the days of unrest in March and even some weeks later, policemen could not move around in uniform without attracting condemnation from the population. The change of regime provided an opportunity to operate a qualitative shift in security sector governance by making this an integral part of the overall democratic governance of the country. What happened instead was that the security forces, in particular the police, were violently condemned and marginalised because they were accused of having served as the repressive arm of the dictatorial regime. Even worse, defence and security institutions were overlooked, relegated to the background and provided with negligible resources. 
Twenty years later, Mali was to pay a high price for this negligence. Faced with the upsurge in transborder and transnational crime, starting from 2000, individuals, communities and local and national elected officials had started to raise many questions and call the attention of the authorities to security matters. However, due to the failure to implement sufficiently in-depth reforms, ten years later in 2012, hordes of narco-terrorists allied with a group of irredentists razed the institutional and democratic structure to the ground in just a few days. Due to lack of adequate training and equipment, and above all lack of motivation, the defence and security forces were incapable of containing the enemies of the republic.

In the first part of this study, we shall review the state of security sector governance prior to the launch of the 2005 reform process. The second part will describe the stages in the process of policy change conducted up to the events of January 2012. The third part will touch on the roles of various actors and the challenges of reform. Finally, in the fourth part we shall review some of the outcomes and suggest proposals for creating the best possible conditions to enable the reform process, which is even more vital for Mali today, to be continued and enhanced. In the conclusion, we shall examine the prospects for security sector reform in Mali.

\section{The state of security sector governance prior to the reform}

The system of security sector governance in Mali dates back to colonial times and is characterised by a half century of accumulated flaws from this period. Indeed, for many years, the security sector was plagued by a lack of leadership, vision, strategy, communication and good governance. Up to 2009, the authorities had never adopted a single official, public security policy document, nor had they initiated any analysis on possible fundamental changes in the paradigms of security governance. For fifty years, security matters were kept out of public debate and excluded from democratic control. As a result, people generally felt that security was the exclusive domain of the security services. This led to total disinterest in the governance of this sector on the part of the population. Over time, this situation has become extremely detrimental to the efficiency of security services, in particular when they required the collaboration of the general public in fighting against insecurity and organised crime. Finally, although a number of mechanisms for the control of the security services do exist formally, they have never functioned effectively, probably due to the exclusive, sensitive and sovereign nature of the security sector.

The institutional framework in Mali makes a clear distinction between defence and security. Since 1992, they have been under two different ministries; the ministry of defence and former combatants and the ministry of internal security and civil defence. Defence is solely responsible for the armed forces. 
Security includes the police and civil defence, which have civilian status, as well as the gendarmerie and the national guard, which are military forces. The gendarmerie and the national guard are managed by law by the ministry of defence, but they are placed at the disposal of the ministry in charge of security. This blend of forces is actually meant to make up for the deficit in human, material and financial resources.

Security institutions function in accordance with international law. The security services were established in accordance with existing legislation and regulations in Mali (laws, decrees, ministerial orders, administrative decisions, etc.). They are under the orders of the democratically established civilian authority. The budget allocated for security is included in the planning of the national budget, which is submitted to the council of ministers and the national assembly for approval. Expenditure by the security services is not subject to state secrecy. The information is available to all and the resources are managed by specialised public administration departments in the ministry of security.

Security in Mali falls within the public domain. The missions and prerogatives of the security services are defined by the constitution of $1992 .{ }^{1}$ Institutional mechanisms are responsible for their functioning and management. In practice, security sector governance in Mali has to take account of some deeply entrenched endogenous security management mechanisms, in particular in the hinterland. In rural areas in particular, communities more often call on custom and traditional authorities (chiefs, qadis, imams, griots, etc.) when dealing with local security governance. This is one of the emergent issues of democratic security sector governance in Mali.

The national assembly is responsible for direct control of the security services through its oversight of government activities and may put questions to the authorities in charge of security at any time. The 'parliamentary committee on defence, security and civil defence' is in charge of considering security matters, analysing them and taking such decisions as are required by law: If necessary, it may question the minister or other security officials.

Furthermore, various provisions of the constitution confer political control over the armed and security forces on the president of the republic, who is commander in chief of the armed forces. ${ }^{2}$ The president of the republic presides over the higher council for national defence and the national defence committee, which are responsible for defence policy in military management and crisis management respectively.

The judiciary also has constitutional and legal prerogatives to control the security sector. Under the terms of the code of criminal procedure, the judicial police, made up of police officers, is mainly in charge of recording crimes and offenses, of gathering evidence of such infringements and of identifying the perpetrators. Judicial police officers are agents of the justice system who work under the authority and the responsibility of the office of the prosecutor. The 
judicial power also includes mechanisms for control of the security services, in the form of certain provisions of martial law, as well as military tribunals and courts.

The existence of all these institutional control mechanisms was nevertheless not enough to prevent the dysfunctions, excesses, shortcomings and failures that came to light in 2012. Why? Because in reality, parliamentary control in Mali is often limited to adopting the security budget and considering draft bills and, very rarely, to putting questions to the minister in charge of security. Parliamentarians have never initiated any draft bills in this area. This phenomenon is due first of all to the lack of adequate knowledge about security sector issues and also to the fact that, like all ordinary citizens, parliamentarians believe that security is a 'reserved domain'. In addition, government has always communicated very little about security matters and there is a clear lack of political will to subject the security sector to democratic control.

Since the beginning of the 21 st century, the country has experienced increasing insecurity. In addition to the existing risks and vulnerabilities, the most worrying threats have come from organised crime: trafficking in drugs, weapons and human beings, cybercrime and terrorism. These criminal activities have had immeasurable effects on human security, social cohesion, enjoyment of human rights, political stability and the efforts to build a democracy and ensure development. The weaknesses in security service oversight and delivery have heightened the country's vulnerability.

Security sector governance faces two types of challenges. There are firstly the numerous, physical security challenges that take various forms and, secondly, the abundant and varied issues of governance in the security sector.

The issues related to governance include the lack of leadership or a vision and strategy, as well as the lack of communication or a system for managing resources; inadequate personnel, training and equipment; the absence of a framework for coordinating the actions of the security forces and for consultation with other actors in the security sector. Finally, strategies have not been adapted to take account of new forms of criminal activity, in particular cybercrime and transborder and transnational crime. All of these make it clear that there is a need for a new form of security sector governance that will transform security into a factor of social cohesion, national unity and development. To achieve this some of the fundamental paradigms of security will have to be modified, but this also implies that people are ready in their minds to accept the idea of change.

How then can the requirements of democratic participation be reconciled with the exclusivity of security services? How can parliamentarians, communities, civil society organisations and sometimes individuals be enabled to contribute to establishing a secure environment at a time when the security forces themselves are unable to tackle the multiple internal and external security challenges head on? The answer lies in making security an integral part of 
the overall democratic governance of the country and promoting a new form of governance that enables direct and indirect control of the security services by parliament, as well as the community and individuals, respectively. This will improve the overall framework for security sector governance.

\section{The process of change: towards security sector reform}

\section{A nascent atmosphere of change in security policy}

Following the traumatic events of 1991, the security services, in particular the police, began to think about their future and the nature of their mandate. However, it was not until 2001 that structured debate actually took place during the 'Journées de reflexion de la police nationale. This time of reflection was organised on the initiative of the general directorate of the national police service and took place in Bamako from 21 to 23 February 2001. It was an opportunity to review some of the difficulties facing the security forces in areas such as human and material resources, logistics, finances and infrastructure. Participants in the three days of reflection also spoke about the possible new face of the police service describing it as one:

"whose presence will enhance the feeling of general security by the public; one that observes the law and individuals' rights in carrying out its missions; that remains discreet in order to gather information, communicate with citizens, prevent crimes and offences and improve the efficacy of its services to the general public; that is tolerant of the surrounding traditional and socio-cultural concepts, in order to preserve the social harmony of families and the community; that is disciplined in organising and executing its traditional and specific public security missions, and one that is strong enough to protect persons and goods and fight banditry and crime, in line with existing legal regulatory and administrative provisions." (DGPN 2001:4)

In 2003, the permanent secretary of the ministry of security and inspectorgeneral of police, Anatole Sangaré, presented the overall approach of his ministry to a visiting delegation from the Nigerian Centre for Strategic Studies that had travelled to Bamako to learn about the experience of Mali in the area of security sector governance. This approach focused mainly on developing a policy of prevention, consolidating the basis for community policing (politique de proxmité) and clarifying and harmonising different security roles. It also sought to adapt means to immediate ends, consolidate and enhance public outreach and pursue a meaningful communication strategy. Based on these elements, the ministry intended to adopt a national security policy that was described as "pragmatic and consistent, in an environment characterised by 
apparently contradictory demands; on the one hand, the need to preserve public order and state stability and on the other, the need to ensure the rule of law and respect of individual fundamental rights, as well as our tradition of tolerance and hospitality" (MSIPC 2003a: 7).

For the implementation of these guidelines, the ministry drafted an operational plan covering seven priority intervention areas: enhancing the security of persons and goods; enhanced operational capacity of the security forces; improved design of the security coverage structure; adapting the legal framework; design of a real communication policy; improving the methods of governance and promoting a policy of bilateral and multilateral cooperation (MSIPC 2003b: 4).

The reflection exercise named 'Journées de reflexion de la police nationale' did not result in a security sector reform project. This may be due either to some form of self-censorship on the part of the security forces, or the fact that the required approval from the hierarchy was not forthcoming. The police service is a vertical structure where even general analysis has to be driven by the superstructure. It took four years for another opportunity to arise in 2005. Prior to that, in 2003, there were signs that the hierarchy was more aware of the values and criteria of sound security sector governance, but these values had not yet been shared with the grassroots and even less with other security sector agencies. The very concept of security sector reform was far from the minds of those involved. Nevertheless, some key players had begun to realise that there was a need to move towards the change for which the general public had long been calling. All it needed was something to trigger off the whole process. In reality, various warning signals had been going off and others were to sound even more alarmingly and sometimes rather suddenly. The events of March 2005 therefore became a catalyst for another attempt at reform.

\section{Triggers of the reform process}

On 27 March 2005, an event that could have been quite banal set off a shockwave. An African Cup of Nations eliminatory round football match between Togo and Mali ended with a win by the visiting team. Throughout the night, a horde of hooligans, joined by thousands of young people, occupied and ransacked Bamako, the capital city. Law enforcement forces failed to protect the population and indeed were completely absent during these events. This violent reaction was a way for idle youth to express their dissatisfaction at the difficulties facing them daily, which included endemic unemployment, poverty and deprivation, marginalisation and exclusion. It was a way for them to challenge the authority of government, whom they blamed for all their woes, and to express their disgust with its system of management. The spontaneity and the degree of violence of events caught everyone unawares, including the president of the republic. ${ }^{3}$ On 7 April 2005, the prime minister met with civil society 
representatives who expressed their exasperation and demanded the establishment of a strong state that could guarantee the safety of persons and their property and that nevertheless would not be a dictatorship. This situation highlighted at least three systemic shortcomings in security sector management:

- Malfunctions related to the breakdown of government authority and poor communication, which meant that there was a need for an in-depth analysis of the security sector;

- A government system of management where rewards were distributed more readily than responsibilities;

- A considerable absence of accountability and efficiency on the part of public security forces, with regard to the resources allocated to them.

Following these events, the responsible authorities were removed from their positions, but this was not enough to appease the general public, who called for deeper change. And yet those involved in the security sector did not all have the same degree of awareness or the same vision of change. Within the security services, many felt that all that was needed to allay this dissatisfaction was an amendment of existing texts and some improvements in the living and working conditions of security agents. A small number of them, as well as a good part of civil society actors however realised that the security situation was in need of a new form of security sector governance in order to meet the requirements of democracy and deal with major security threats such as drugs, weapons and human trafficking, natural disasters, the presence of Algerian Salafists on the national territory, etc. It is against this backdrop that the minister of internal security and civil defence launched the General Assembly on Peace and Security in Mali (Etats généraux de la sécurité et de la paix au Mali) in 2005.

\section{Major implementation milestones and developments in the reform process}

The idea of holding the General Assembly on Peace and Security in Mali was put forward by the ministry in charge of security. This meeting became the entry point for the security sector reform process and marked a historic moment in the annals of the sector in Mali. For the first time since independence in 1960, the security services were making overtures to other actors in the sector. No subject was taboo and all the issues were raised and debated. It was a gathering of flag officers and farmers, soldiers and hunters, police and herders, senior civil servants and labourers, women, men, young people and the elderly. The participants worked together to identify the security challenges, assess the security needs of the population and propose solutions, as well as the most desirable form of national security sector governance. 
The General Assembly on Peace and Security in Mali took place from 21 to 23 November 2005 under the auspices of the ministry of internal security and civil defence and was attended by the president of the republic, President Amadou Toumani Touré. The event had been prepared in three successive phases. During the first phase, the ministry sent out missions, travelling sometimes all the way to communes and villages to raise awareness among various stakeholders about the need for national debate on security matters and to gather their reactions. During the second phase, the ministry organised regional consultations spearheaded by the regional governors, on major themes such as urban and peri-urban banditry, the proliferation of light weapons, community conflict management, rising religious intolerance, transborder crime, etc. The third phase was the actual event in Bamako where 245 participants from various walks of life attended the General Assembly. There were representatives of government, the general administration and the administrative regions, commanders of military regions, defence and security forces, civil society, the private sector, political parties, local authorities, communities and technical and financial partners.

The General Assembly on Peace and Security in Mali was assigned four objectives:

- To encourage all categories of the population to participate actively in a discussion of security issues and the design of a coherent and harmonised security programme;

- To identify the components of a 'national security policy' by examining the problems in the security sector from different points of view;

- To put together the makings of a draft security orientation and planning bill;

- To establish a framework for consultation, coordination and participatory management of security issues, involving all security sector actors.

To meet these objectives, participants alternated between plenary sessions and workshops over the three-day period, with accounts from senior officials and also ordinary citizens who recounted their experience of security in Mali. The inaugural presentation focused on security issues in West Africa and was followed by 21 other presentations on topical subjects. The workshop discussions were centred on five major themes: 21 st century societies and the emergence of new risks; the precautionary principle and the culture of prevention; security and decentralisation; security and intercommunity conflicts and security agents and accountability. Each workshop was run by a moderator and the discussions were collated by a rapporteur, working closely with the general rapporteur of the event.

With regard to the vision of security, two conceptions emerged from the General Assembly. Most of the security forces called for enhanced government 
authority and the reinstatement of a strong state in order to provide security. The other stakeholders, in particular those from civil society, political parties and local authorities (communities), who represented the vast majority, called for a new vision based on more democratic security sector governance where the individual would be the central focus of security concerns. In various communications and presentations, appeals were made for this new vision to be based on human security (MSIPC 2005). The supporters of this predominant approach were convinced that a security system that was based on democratic governance and focused on the individual would give renewed impetus to development. This vision is based on the fact that the end of the cold war also marked the end of inter-state conflicts. The centre of gravity of threats has now suddenly swung from external factors to internal factors, thus revealing a multitude of vulnerabilities, risks and real threats to peace and national security. The proponents of this approach pointed to the fact that violence was spreading at all levels of society and emphasised the need to review the conventional state-centric approach to security. Ultimately they stated that while state security must be assured, from now on human security must be the first priority.

On 23 November 2005, after three days of intense, frank and open debate, 127 recommendations were published. The following are among the key recommendations:

- Drafting of a national security policy based on a new vision (human security) and a new comprehensive strategy (prevention);

- Implementation of a programme for shared governance of peace and security;

- Design and implementation of a communication strategy to promote shared governance of security and peace;

- Drafting of a long term action plan for implementing the strategic pillars of the national security policy, with the aim of moving towards a security planning act.

These recommendations outlined a road map for improving the democratic quality of security sector governance in Mali and identified the first step as the drafting of a new national security policy.

\section{National security and civil defence policy}

In the wake of the General Assembly on Peace and Security in Mali the ministry of security set up a commission in charge of drafting a national internal security policy and establishing a programme for shared governance of the security sector. These were practical steps in the implementation of security sector reform. The aim of the programme was to make a qualitative contribution towards creating an enabling atmosphere of social peace and political stability 
for economic and social development by integrating security in the overall democratic and developmental governance of the country. The objective was to meet democratic demands, as well as the criteria for good governance and to improve the ability of the security forces to deal with both internal and external factors of insecurity and meet the security expectations of the population.

The national internal security policy took the form of a simple policy outline that emphasised the polysemous, crosscutting and multidimensional nature of security and described the nine strategic pillars that should serve as the backbone of the national security and civil defence policy:

- Prevention of situations that could undermine security;

- Strengthening the capacities of the security forces;

- Enhancing national disaster prevention and management capacities;

- Control of insecurity on roads and rivers;

- Creation of a neighbourhood police service;

- Implementing shared governance in the security sector;

- Anti-terrorism;

- Enhanced bilateral and multilateral cooperation;

- Implementation of a communication strategy to promote a change in attitudes and behaviour.

Through focusing on these areas, the government intended to implement measures that would enhance the national capacity to deal with the broad range and complexity of security problems and ensure an atmosphere of social peace and political stability throughout the country, thus promoting development.

This outline of a national security policy also included a five-year action plan that was to serve as the security sector planning law. The council of ministers postponed the adoption of this action plan for both budgetary and political reasons. The council of ministers felt that the required budget was not available. In addition, the head of state in particular was of the view that a security sector planning law needed to go hand-in-hand with a military sector planning law, which was still pending. Nevertheless, the idea of a programme to support the implementation of a national security policy was approved and gave rise to the establishment of the Programme for Shared Governance of Peace and Security (Programme de gouvernance partagée de la sécurité et de la paix - PGPSP).

\section{The Programme for Shared Governance of Peace and Security}

The implementation of a concept of shared governance of peace and security as an instrument for executing national security policy was a significant starting point for the security sector reform process (Moulaye \& Niakaté 2011). The overall objective of the programme was to contribute to establishing an atmosphere of security, peace and stability, which would promote sustainable 
human development and contribute to poverty reduction in Mali. The programme was assigned three specific objectives as follows: (i) to assist in drafting and adopting a new national security policy, following the General Assembly on Peace and Security in Mali (ii) to support the implementation of the shared governance of security and peace programme at national and decentralised levels and (iii) to support the construction of lasting peace and security in the north of Mali. The programme included the following major activities:

- Drafting and implementation of a national security and civil defence policy framework document, as recommended by the General Assembly on Peace and Security in Mali;

- Capacity enhancement for security and civil defence departments, civil society organisations, the private sector, local authorities and local communities, in the area of security governance;

- Prevention and resolution of community conflicts, in close collaboration with civil society organisations, local government and government representatives;

- Enhancing disaster prevention and management capacities;

- Design and establishment of a pilot municipal police service;

- Drafting and implementation of a communication strategy on shared and decentralised security;

- Promoting a culture of peace;

- Control of light weapons, etc.

The programme also provided assistance to various national institutions (national assembly, economic and social council and the ministries of local government, defence, women's promotion, justice, etc.). The programme provided technical and financial assistance to numerous communities, local authorities and civil society organisations involved in conflict prevention, management and resolution. The opportunities for dialogue and consultation that it provided generated valuable debate on security issues in the country. These discussions often inspired the artisans of peace and those involved in the security sector and helped them to identify appropriate solutions which contributed to consolidating peace and security in the hinterland of Mali. Finally, the programme was able to build a network of partners, which contributed significantly to its funding. These results are even more important as they relate to the most valuable assets of a nation, namely its citizens. They enabled some actors to realise the importance of investing in security, an area which until then had been totally foreign to them. With conviction and perseverance, the programme was able to involve other stakeholders and thus attain a critical mass that made the reform process irreversible.

By the end of the three years of implementation (October 2008 - December 2011), the programme had achieved some remarkable results that included the 
drafting of a national internal security and civil defence policy framework document. Furthermore, a number of studies were carried out and served to consolidate the basis of the reform. These include a feasibility study on a communal police service, a study on the establishment of a database on criminal activity and a study on the communication strategy, with a communication plan for the ministry of internal security and civil defence.

The positive results of the PGPSP include about a hundred capacity building events organised for security sector stakeholders, in particular lecturedebates on security challenges in Mali, Africa and the rest of the world, as well as on institutional responses and the issue of security sector reform. The PGPSP also focused on a number of training activities including training 170 security agents in public accounting in order to improve financial management of the security sector. 50 agents were also trained on airport safety. The programme also included a component focusing on involving communities, whereby 15 intercommunity or intercommunal meetings were organised, as well as a local governance capacity building support project for the Kidal region, which was facing specific difficulties in the area of security and grassroots development.

Beyond these results, the programme kick started the process of civil society involvement in security sector governance, which continued independently of the upheavals in the country. Communities in particular became more aware of the need for concentrated efforts to build peace and security as the prerequisites of local development. The resources allocated to the programme also helped to mitigate the usual atmosphere of suspicion between civilians and the military, appease some social tensions and reduce the level of violence in the country. However, all of this was not enough to meet the immense security needs and turned out to be ineffective against emergent threats such as organised crime.

All of the militant forces of the nation were represented at the General Assembly in November 2005. They helped to start the security sector reform process, but not all of them demonstrated the same level of determination. Civil society organisations and grassroots communities were the most enthusiastic. For some of these non-state actors, it was the first time that their status and usefulness were being given full recognition and they were convinced that reforms would respond to some of their concerns. They therefore engaged fully in the debate.

One year after the holding of the General Assembly, it was clear that the most positive reaction to this initiative had come from civil society. In fact, several civil society organisations working on peace, security and human rights came together to form the National Coalition of Civil Society for Peace and the Fight against the Proliferation of Small Arms (Coalition National de la Société Civile pour la Paix et la Lutte contre la Prolifération des Armes Légères CONASCIPAL). They spontaneously decided to support government efforts to promote democratic security sector governance. In January 2007, CONASCIPAL organised the first national civil society forum on democratic security sector 
governance in Mali. The report of this forum was published (Moulaye 2008). From that date, people throughout the country began to demonstrate a real acceptance of the ideals of the reform and various information, awarenessraising and training activities were organised, as well as intercommunity and intercommunal meetings.

During the General Assembly on Peace and Security in Mali, the defence and security forces remained in the background, although they did make their voices heard. They however frequently referred to their duty to maintain a certain reserve and the fact that they were unused to speaking out in public. In reality, many members of the armed forces were not optimistic about the success of the reform process, which may be quite normal because learning to live in a democracy also implies a culture of questioning things. However, such questions must lead to analysis, followed by bold commitment. A few officers nevertheless realised what was at stake, right from the start. They understood the need for reform and the positive effects that it would have for the country in the future. They got fully involved in the process, but there were only a handful, none of whom held decision-making positions. Although the military hierarchy constantly spoke out in support of the initiative, with the benefit of hindsight, it appears that this support was only superficial. Some other individual stakeholders were also very active, generally researchers who made decisive contributions to the analysis of the security situation, as well as to the understanding of certain concepts and approaches.

The ministry received support from UNDP in organising the General Assembly because the Malian government had made certain statements that appeared to show that human security would be the pivotal concept orientating the overhaul of the security sector. Since the UNDP was promoting this concept at the time, they were initially the only partner involved in the reform process. Subsequently, Norway, Luxemburg and Switzerland also provided strong support to the initiative. The support from UNDP to the reform process was initially cautious and consisted mainly of organising consultations in the hinterland, in addition to the General Assembly on Peace and Security in Mali. Later on, the UNDP granted a budget extension for the design and implementation of the PGPSP. ${ }^{4}$

\section{Conclusion: Lasting change and prospects for consolidating reform}

A few weeks after the General Assembly, the ministry of security drafted a fiveyear action plan (2008-2012) aimed at implementing all the 'hard' and 'soft' aspects of security sector reform, with a budget of FCFA 88.4 billion. The action plan was to be submitted to government for approval, in the form of a security planning act. The expected sources of funding were the government budget 
and external contributions to be gathered through a sector roundtable meeting. The project was however not approved by government, under the pretext that a military planning act had first to be adopted. This clearly demonstrates the absence of the required political will at the highest level of state and highlights the competing parochial interests between defence and security. In reality, government had not assigned any substantial resources to security sector reform and was rather counting on the support from the sector roundtable meeting of UNDP and other external donors, which is a reflection of the degree of political will or lack thereof.

At various times in the reform process this lack of political will was made manifest. For example, it took a very long time for the national, internal security and civil defence policy framework document to be finalised. It was initiated in January 2006, but was not adopted by the council of ministers until October 2010. Such a length of time either shows a lack of strong determination or internal tensions regarding its content. Similarly, the shared governance of security and peace in Mali programme was designed in 2006, but was not implemented until 2008. There again, the two-year delay appears to indicate a lack of strong political will.

Since the president of the republic and commander in chief of the armed forces was also a former senior officer, one wonders whether he was really in favour of security sector reform. Why did he want to tie the military planning Act to the security planning Act? Was he afraid of the differences that the reform could create between the armed and security forces? Was he aware of the reluctance of certain military officers with regard to any form of reform in the defence sector? Did he realise that by delaying the planning act he was undermining the whole process of security sector reform? These are some questions that legitimately come to mind after the fact.

In practice, the reform efforts were mainly limited to implementation of the activities under the PGPSP. Poor government enthusiasm for the reform led UNDP to withdraw from the programme as soon as its financial contribution was exhausted. Meanwhile, certain actors such as civil society organisations, local authorities and the communities, continued to call for the technical and financial support of this UN agency, which shows that they were interested in pursuing the reform process.

In reviewing the events, it appears that internally, there should have been more in-depth communication from the start, as many stakeholders within the security forces and even more outside (civil society, political circles, private sector, local authorities and communities) had no idea of what was involved in reforming the sector. A good part of the security hierarchy was not convinced of the usefulness of the exercise or feared its effects on their personal privileges.

Externally, funds had to be mobilised to carry out reform activities, but most external partners felt that security was an area of national sovereignty where they could only intervene on the basis of an express request from the 
Malian government. Furthermore, the security services themselves had little experience of development programmes funded directly through international cooperation. The security forces were thus not used to the methods for mobilising external resources and tended to keep to themselves because of their duty to maintain a certain reserve. The solution found was to promote democratic security sector governance so that security would be considered by partners as an area that was open to official development aid, in the same way as health or education.

Obviously, things could have gone differently if there had been greater political will at the highest level of state and stronger commitment on the part of all the institutions of the republic. It would have helped if senior security officials had not been so reluctant and if right from the start, the defence and security forces had understood that security sector reform was a broad-based undertaking. They should all have worked together to ensure its success. Ideally, Mali should have had a single, overarching reform programme based on a 'single vision, a comprehensive strategy, synergy of action and appropriate communication'. Instead, several programmes working in the fields of peace and security coexisted without any organisational link and failed to collaborate in their activities. Merging them all would have gone against certain personal interests and ambitions.

In the end, the only component that was implemented relatively satisfactorily was the awareness-raising on security challenges and the need for security sector reform that involved a wide range of stakeholders. Only civil society organisations, local authorities and grassroots communities demonstrated genuine interest in the reform process. There are therefore whole areas of the reform process that still need to be designed and implemented, in particular those related to legislation and regulations that would induce a true transformation. The concept of shared governance of security has made some headway. It needs to be broadened in order to open the way for effective security that will underpin sustainable development.

In the light of the unfortunate events of 2012, attitudes have evolved considerably in Mali. The humiliation of the defence and security forces and the psychological shock to the Malian people were such that today no one is against security sector reform. What is required now is to find the most appropriate, intelligent, reliable, effective and efficient way to go about it.

On 30 December 2013, the ministry of security relaunched the reform process with the establishment of a 'multidisciplinary analysis group on security sector reform. The ministry of defence, which had been rather reluctant in the past, also set up a defence review commission. It would be better if both ministries could work together to transform the security sector and thus design a shared vision, a national domestic security policy and a national defence strategy that would lead to a more peaceful environment, a factor that is more conducive to productive investment and sustainable development. Such an 
undertaking should be lodged within the office of the president in order to facilitate decisions, coordination and synergy in action. This would make up for the past lack of leadership and political backing and ensure greater buy-in from institutional actors, something that had been missing in the initial phase of the reform process.

\section{Notes}

${ }^{1}$ The Constitution of the Republic of Mali was passed on 25 February 1992.

${ }^{2}$ See, for example, Title III, Art. 44 of the 1992 Constitution.

${ }^{3}$ Meeting between the president of the republic and the press (8 June 2005) on the occasion of the 3rd anniversary of his accession to power.

${ }^{4}$ For a report on this programme, see Moulaye and Niakaté (2011). 